\title{
Distinguishing between farmed and wild-caught black tiger Prawns, Penaeus monodon, using stable isotopes
}

\begin{abstract}
Determining farmed from wild-caught seafood is important to alleviate public health concerns associated with food safety as well as combatting food fraud. This study applied stable isotope analysis (SIA) to determine provenance of farmed and wild-caught black tiger prawns, $P$. monodon. Isotopic analysis showed that wild $P$. monodon were significantly enriched in $\delta^{13} \mathrm{C}(p<0.0001)$ compared to those that were farmed. The results of this case study suggest SIA can be used effectively to differentiate between farmed and wild-caught black tiger prawns, and potentially to determine the production method for other seafood commodities.
\end{abstract}

Keywords: aquaculture, prawns, stable isotopes, provenance
Volume 7 Issue I - 2018

\author{
Karthik Gopi,' Debashish Mazumder, ${ }^{2}$ Neil \\ Saintilan, ${ }^{3}$ Jesmond Sammut ${ }^{\prime}$ \\ 'Centre for Ecosystem Science, The University of New South \\ Wales, Australia \\ ${ }^{2}$ Australian Nuclear Science and Technology Organisation, \\ Australia \\ ${ }^{3}$ Department of Environmental Sciences, Macquarie University, \\ Australia
}

\author{
Correspondence: Debashish Mazumder,Australian Nuclea \\ Science and Technology Organisation, Locked Bag 200I, \\ Kirrawee DC, Australia, \\ Email debashish.mazumder@ansto.gov.au
}

Received: January 03, 2018 | Published: January 09, 2018

\section{Introduction}

The United Nations predicted the global population to reach between 8.1 billion and 10.6 billion by $2050 .{ }^{1}$ With the increase in global population, there will be a commensurate increase in food consumption. Seafood has been recommended as a component of a nutritional diet by many authorities because it is considered an essential source of omega-3 fatty acids, protein, vitamins and iodine. ${ }^{2,3}$ The importance of seafood is highlighted by its high market value, which is around \$94 billion USD annually. With seafood consumption increasing globally, and with $44 \%$ of the world's fisheries being fully to heavily exploited, the only sustainable solution is the use of aquaculture to meet demand. ${ }^{4}$ Black tiger prawn (Penaeus monodon) is a commercially-valuable species farmed widely in Asian-Pacific countries because global demand is high, and the commodity, thus, lucrative. ${ }^{5}$ However, intensification of prawn aquaculture has raised concerns over food safety due to presence of residual antibiotics, heavy metals, hormones and pathogens that present a risk to human health. ${ }^{6}$ Banned substances, like antibiotics, have been found in farmed seafood imported into several countries. ${ }^{7}$ Over recent years, there have been recurrent reports of substitution of expensive seafood products with cheaper commodities leading to what can be described as food fraud. ${ }^{8}$ This illegal practice is of particular concern for the prawn industry because the commodity is often traded across a wide geographic area. Therefore, seafood, such as prawn, is immensely important not only to ensure public health and safety, but also for the sustainability of the industry, whether based on aquaculture or dependent on the wild fishery. Currently, seafood provenance identification relies on several techniques, with DNA most commonly used. ${ }^{9}$ However, DNA profiling cannot ascertain production methods because the differences in the DNA of farmed and wild-caught prawns, and other seafood commodities, are unlikely to be significant. ${ }^{10,11}$ Stable isotope analysis (SIA) has become an important technique in trophic ecology. ${ }^{12}$ The stable carbon isotopes $\left({ }^{13} \mathrm{C} /{ }^{12} \mathrm{C}\right)$ indicate the sources of nutrients, while the nitrogen isotopes $\left({ }^{15} \mathrm{~N} /{ }^{14} \mathrm{~N}\right)$ may indicate the trophic level of an organism in the food web. Because the isotopic values of a consumer are related to the composition of the diet, ${ }^{13}$ the differences in such diets, stemming from changes in farming practices, would be reflected in the isotopic profile of consumer muscle. The aim of the case study is to apply stable carbon and nitrogen analysis to distinguish between farmed and wild-caught $P$. monodon.

\section{Materials and Methods}

A total of 14 P. monodon (average $12 \mathrm{~cm}$ ), farmed ( $\mathrm{n}=7$ ) and wildcaught $(\mathrm{n}=7)$, were collected from subtropical Queensland in Australia. The farmed prawns were collected randomly from different ponds in the same farm. White muscle tissues of the prawns were oven-dried at $\sim 60^{\circ} \mathrm{C}$ for 48 hours and homogenised to fine powder. Powdered samples were analysed in the isotope ratio mass spectrometer (EA-IRMS; Thermo Fisher Flash 2000 HT EA, Thermo Electron Corporation, U.S.A) at Australian Nuclear Science and Technology Organisation. A two-point calibration was employed to normalise the isotope data, utilising standards that bracket the isotope ratios of the samples being analysed. Both standard and quality control references were included in each run, including replicate analysis of samples. Results were precise $(+1 \mathrm{SD})$ to $1 \%$ for both $\% \mathrm{C}$ and $\% \mathrm{~N}$ and $0.3 \%$ for $\delta^{13} \mathrm{C}$ and $\delta^{15} \mathrm{~N}$.Values for $\delta^{13} \mathrm{C}$ and $\delta^{15} \mathrm{~N}$ were expressed in parts per thousand or per mil (\%) deviations from standard values for the two elements and determined through standard analytical procedures. ${ }^{14}$ As lipid content in the muscle tissue affects $\delta^{13} \mathrm{C}$ values [15], we employed the widelyused mathematical formula from Post, Layman ${ }^{16}$ for normalisation adjustment if the $\mathrm{C}: \mathrm{N}$ ratio was higher than 3.5 :

$$
\delta^{13} C_{\text {normalised }}=\delta^{13} C_{\text {untreated }}-3.32+0.99 \times C: N
$$

The results were then plotted and validated using an Analysis of variance (ANOVA).The results were analysed using R Studio version 1.0.143. ${ }^{17}$ 


\section{Results and Discussion}

Stable carbon isotope value for wild $P$. monodon was enriched substantially (about 4.36\%) from farmed P. monodon, while the enrichment for $\delta^{15} \mathrm{~N}$ was opposite to wild prawn, farmed prawn was $0.74 \%$ higher than wild-caught prawn (Table 1). The bi-plot (Figure 1) and ANOVA revealed that the farmed $P$. Monodon were significantly different from wild-caught specimens in terms of $\delta^{13} \mathrm{C}(p<0.0001)$ and $\delta^{15} \mathrm{~N}(p<0.00034)$

The results of this study clearly determined farmed from wildcaught prawns on the basis of stable isotopes. Other studies, which have focused on the use of SIA to discriminate between the aquaculture from the wild-caught prawns, have had similar results. For instance, Gamboa-Delgado, Molina-Poveda ${ }^{18}$ found that wild-caught Pacific white shrimp had significantly enriched $\delta^{13} \mathrm{C}$ and $\delta^{15} \mathrm{~N}$ values when compared to the farmed samples. Ortea \& Gallardo $^{19}$ found that SIA was able to distinguish the production methods of seven different shrimp species. The enriched $\delta^{13} \mathrm{C}$ values of the wild-caught $P$. monodon are linked to their diet comprised of various components available in natural systems, such as benthic diatoms, phytoplankton, macroalgae and seston processed enriched $\delta^{13} \mathrm{C}$ values. ${ }^{20-22}$ The higher $\delta^{15} \mathrm{~N}$ values in the farmed P. Monodon can be attributed to the nitrogen enriched animal-based protein feed ${ }^{23}$ consistently used under intense farming. The results of this case study suggest stable carbon and nitrogen analysis could prove to be an effective analytical tool to determine farmed from wild-caught prawns, and has potential for other seafood commodities. However, to increase resolution and predictability, SIA should be used in conjunction with other techniques such as elemental analysis, fatty acid profiling and DNA profiling.

Table I: Stable carbon and nitrogen isotope values of farmed and wild-caught $P$. monodon from subtropical Queensland, Australia.

\begin{tabular}{|c|c|c|c|c|c|}
\hline Type & $\delta^{13} \mathrm{C}$ & $\delta^{15} \mathrm{~N}$ & Type & $\delta^{13} \mathrm{C}$ & $\delta^{15} \mathrm{~N}$ \\
\hline Farmed P. monodon & -20.69 & 8.31 & Wild-caught P. monodon & -16.25 & 7.79 \\
\hline Farmed P. monodon & -20.69 & 8.35 & Wild-caught P. monodon & -17.07 & 7.36 \\
\hline Farmed P. monodon & -20.36 & 8.44 & Wild-caught P. monodon & -15.98 & 8.04 \\
\hline Farmed P. monodon & -20.85 & 8.53 & Wild-caught P. monodon & -16.1 & 7.79 \\
\hline Farmed P. monodon & -20.55 & 8.31 & Wild-caught P. monodon & -16.47 & 7.35 \\
\hline Farmed P. monodon & -20.88 & 8.12 & Wild-caught P. monodon & -16.5 & 7.38 \\
\hline Farmed P. monodon & -20.75 & 8.53 & Wild-caught P. monodon & -16.9 & 7.69 \\
\hline Mean ( \pm s.d.) & $-20.68(0.18)^{a}$ & $8.37(1014)^{b}$ & Mean ( \pm s.d.) & $-16.32(0.39)^{a}$ & $7.63(0.26)^{b}$ \\
\hline
\end{tabular}

Note: Column values with different letters indicate significant differences at $\mathrm{P}<0.05$.

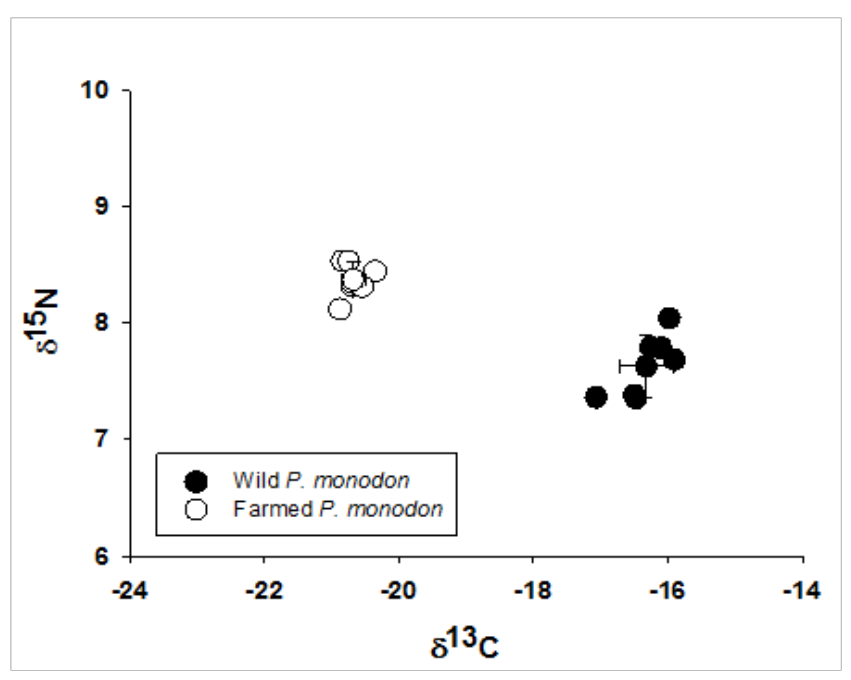

Figure I Stable isotope bi plot indicating individual and mean values of farmed (empty circle) and wild-caught (black circle) P. Monodon.

\section{Acknowledgement}

The authors would like to thank Prof Marie-Claude and Prof Henk Heijnis (ANSTO) for their support and the Australian Institute of Nuclear Science and Engineering (AINSE) for providing funding to present this research at the Asian-Pacific Aquaculture conference 2017.

\section{Conflicts of Interest}

None.

\section{References}

1. Ezeh AC, Bongaarts J, Mberu B. Global population trends and policy options. The Lancet.2012;380(9837):142-148.

2. World Health Organization. Food based dietary guidelines in the WHO European Region. Copenhagen, Denmark: WHO. 2003.

3. Sioen I, Matthys C, De Backer G, et al. Importance of seafood as nutrient source in the diet of Belgian adolescents. Journal of Human Nutrition and Dietetics. 2007;20(6): 580-589.

4. Kearney J. Food consumption trends and drivers. Philosophical Transactions of the Royal Society B. Biological Sciences. 2010; 365(1554): 2793-2807.

5. https://www.csiro.au/en/Research/AF/Areas/Aquaculture/Premiumbreeds/Black-tiger-prawn.

6. Mansfield B. Is fish health food or poison? Farmed fish and the material production of un/healthy nature. Antipode.2011; 43(2): 413-434.

7. Souid $\square$ Mensi G, Serge M, Khira M, et al. Combined cytotoxicity and genotoxicity of a marine toxin and seafood contaminant metal ions (chromium and cadmium). Environmental toxicology. 2008;23(1): 1-8. 
8. Buck EH. Seafood marketing: combating fraud and deception Congressional Research Service, Library of Congress. 2007.

9. Primrose S, Woolfe M, Rollinson S. Food forensics: methods for determining the authenticity of foodstuffs. Trends in Food Science \& Technology. 2010;21(12):582-590.

10. Carrera E, García T, Céspedes A, et al. Identification of Smoked Atlantic Salmon (Salmo salar) and Rainbow Trout (Oncorhynchus mykiss) Using PCR-Restriction Fragment Length Polymorphism of the p53 Gene. Journal of AOAC International. 2000; 83(2):341-346.

11. Mc Ginnity P, Stone C, Taggart JB, et al. Genetic impact of escaped farmed Atlantic salmon (Salmo salar L.) on native populations: use of DNA profiling to assess freshwater performance of wild, farmed, and hybrid progeny in a natural river environment. ICES Journal of Marine Science. 1997;54(6):998-1008.

12. Fry B. Stable Isotope Diagrams of Freshwater Food Webs. Ecology. 1991;72(6):2293-2297.

13. Mazumder D, Li Wen B, Mathew Johansen PA, et al. Inherent variation in carbon and nitrogen isotopic assimilation in the freshwater macroinvertebrate Cherax destructor. Marine and Freshwater Research. 2016;67(12):1928-1937.

14. Ohlsson KA, Wallmark PH. Novel calibration with correction for drift and non-linear response for continuous flow isotope ratio mass spectrometry applied to the determination of $\delta^{15} \mathrm{~N}$, total nitrogen, $\delta^{13} \mathrm{C}$ and total carbon in biological material. Analyst. 1999;124(4): 571-577.

15. Bodin N, Le Loc'h F, Hily C. Effect of lipid removal on carbon and nitrogen stable isotope ratios in crustacean tissues. Journal of Experimental Marine Biology and Ecology. 2007;341(2):168-175.
16. Post DM, Layman CA, Arrington DA, et al. Getting to the fat of the matter: models, methods and assumptions for dealing with lipids in stable isotope analyses. Oecologia. 2007;152(1):179-189.

17. R Studio Team, R Studio. Integrated Development Environment for $R$ RStudio, Inc.: Boston, USA. 2016.

18. Gamboa-Delgado J, Molina P, GodAnez S, et al. Application of stable isotope analysis to differentiate shrimp extracted by industrial fishing or produced through aquaculture practices. Canadian Journal of Fisheries and Aquatic Sciences. 2014;71(10):1520-1528.

19. Ortea I, Gallardo JM. Investigation of production method, geographical origin and species authentication in commercially relevant shrimps using stable isotope ratio and/or multi-element analyses combined with chemometrics: An exploratory analysis. Food Chemistry. 2015;170:145153.

20. Primavera HJ. Stable carbon and nitrogen isotope ratios of Penaeid juveniles and primary producers in a riverine mangrove in Guimaras, Philippines. Bulletin of Marine Science. 1996;58(3): 675-683.

21. Chong V, Low C, Ichikawa T. Contribution of mangrove detritus to juvenile prawn nutrition: a dual stable isotope study in a Malaysian mangrove forest. Marine Biology. 2001;138(1):77-86.

22. Loneragan N, Bunn S, Kellaway D. Are mangroves and seagrasses sources of organic carbon for penaeid prawns in a tropical Australian estuary? A multiple stable-isotope study. Marine Biology. 1997;130(2):289-300.

23. Gamboa-Delgado J, Le Vay L. Natural stable isotopes as indicators of the relative contribution of soy protein and fish meal to tissue growth in Pacific white shrimp (Litopenaeus vannamei) fed compound diets. Aquaculture. 2009; 291(1):115-123. 